\title{
The Integrity of Local Enforcement Officers: Self Proclaim vs Colleague Perception
}

\author{
Nor Balkish Zakaria ${ }^{1}$, Muhammad Farhan Nordin ${ }^{1}$, Rahimah Mohamed Yunos ${ }^{1} \&$ Jamaliah $_{\text {Said }}{ }^{2}$ \\ ${ }^{1}$ Accounting Faculty, Universiti Teknologi MARA, Kampus Segamat, Johor, Malaysia \\ ${ }^{2}$ Accounting Research Institute, Universiti Teknologi MARA, Selangor, Malaysia \\ Correspondence: Nor Balkish Zakaria, Accounting Research Institute, University Technology MARA, Kampus \\ Segamat, Johor, Malaysia.
}

Received: April 30, 2019

Accepted: May 30, 2019

Online Published: June 11, 2019

doi:10.5430/ijfr.v10n5p288

URL: https://doi.org/10.5430/ijfr.v10n5p288

\begin{abstract}
Social development requires the removal of barriers so that all citizens can live with confidence and dignity. This development is driven with integrity, to sustain society trust and wellbeing with the help of local enforcement officers. However, local enforcement integrity issues become more serious since they serve public interest and constantly deals with law offenders and public criminals. This study therefore, examines the effects of demographic, experience and organisational factors on the integrity of local enforcement officers. The data was collected in 2017 from Pusat Latihan Penguatkuasa Selangor, a training centre for local enforcement officers in Malaysia. Based on vignettes survey of 216 respondents, a paired-samples t-test analysis was carried out. The results indicate that there is a significant difference between self-proclaim and colleague perception only in the 'willingness to report' and not 'offence seriousness' category. This study helps local authorities, government, private organisation and the policy makers to ensure integrity issues can be prevented thoroughly in all areas.
\end{abstract}

Keywords: integrity, corruption, self-proclaim, colleague perception and social developments

\section{Introduction}

Corruption issues among government servant are frequently highlighted in television and mass media. Government sector is very vulnerable to corruption because the government governs substantial public fund and it is easy to be embezzled by irresponsible parties. In current economy challenges, corruption exists in many places in the world that can deteriorate the public interest. The lack of integrity attitude is believed to be one of the factors that lead to the corruption activities. According to "Corruption Perception Index (CPI) 2016" reported by Transparency International (2017), Malaysia is ranked at 55th place over 176 countries around the world with a score of 49 out of 100. Improving corruption score is required to attract positive trade investment into Malaysia and reduce income distribution gap for public benefits.

Besides corporate corruption activities such as money laundering, falsifying documentation, misappropriation of assets and abuses of power, smaller scale corruptions at the society level are also crucial to be highlighted as this type of misconducts involved public in mass as potential victims. Based on social development framework, a safe place to live is very important in helping people to achieve self-sufficiency. It is the focus of family life; where families can live safely, nurture their children, build community relationships and care for aging parents. Without a decent place to live, it is difficult to function as a productive member of society.

Social development is about improving the well-being of every individual in society so they can reach their full potential, where society is linked to the well-being of each and every citizen. Other investments in people that contribute to the economic prosperity of society include youth programs and services, post-secondary education, job creation, promotion of healthy, active living and safe and secure communities

As part of social development agenda, safe and secure communities would rely on the monitoring of local enforcement officers (LOE). For instance, LOEs are highly exposed to corruption during their official duties. They are responsible to ensure that all public rules and regulation are followed accordingly and prohibit anyone to violate the law. However, irresponsible individuals still tend to violate the law to fulfil their personal interest. Ignorance about the law by the individuals facilitates the corruption activities among local enforcement officers. The situation 
is getting worse when the wrongdoers bribe the enforcement officer to fulfil their personal interest.

LOE plays crucial role in order to safeguard public interest. They have the obligation to implement rule and regulation, prevent illegal activities and prosecute law offenders. Intense pressures faced by these officers may expose them to corruption activities such as bribery. Raiding illegal premises, protecting public properties and getting threats from criminals make local enforcement profession very risky to be handled. The pressure becomes worse when the local enforcement officers face personal problem, financial distress and negative working environment. Risk of bribery offered from law offenders is very high and hard to be controlled. Dishonest local enforcement officers view bribery as an opportunity to gain extra money and wealth. Furthermore, abuse of power by high rank officers in committing fraud will contribute negative influence on their subordinates.

Regarding this problem, Pusat Latihan Penguatkuasa Selangor (PULAPES) is a training centre in Malaysia that provides education and training assessment to local enforcement officer in Selangor. Professionalism training is important to enhance the leadership and improve ethical attitudes of local enforcement officers. Consequently, high integrity level of local enforcement officers can strengthen the credibility and reputation of organisation in serving the public interest.

Previous literatures frequently discussed corruption and integrity in general contexts. However less focus was highlighted among the local enforcement officers setting especially in less developed and developing countries. Thus, this study addresses several literature gaps with the focus on three major aspects, which are demographic, experience and organisational factors.

The paper is arranged to meet the objectives of this study which are to examine the impact of demographic, experience and organisational factors on integrity among local enforcement officers based on Malaysian setting. In addition, both self-proclaim and colleague perception integrity perspectives will also be examined.

After this introduction section, the previous literature studies section will discuss the prior findings as well as supporting theory. Next section will be the methodology issues pertaining samples and vignette survey. Following methodology, a section of findings and its implication will be elaborated. Finally, the last section will conclude the overall study.

\section{Literature Review}

Based on Philadelphia setting, Hickman, Piquero, Powell, and Greene (2016) examines the presence of moral difference in gender characteristic within a police department. Their results indicate that male police officers will less likely to report their colleagues who convicted physical abusive. This shows that demographic factor also have certain degree of influence to integrity exercises. Goel, Mazhar, and Nelson (2014) find that unmarried individuals are less likely to commit corruption. Single individuals normally live a less stressed life as compared to married individuals due to different level of family commitment. Ikezue and Alawari (2015) examine public perception of corruption. Their results show that public classified corrupted environment as a serious problem and marital status was determined as suitable predictor of corruption in the local government departments. On the other hands, married individuals are more ethical than other marital status. Chatterjee and Ray (2014), examine on the relationship between corruption criminal and corrupt behaviour. The study found that there is a relationship between corruption criminal and corrupt behaviour. Moreover, Mesticka and Cabelkova (2015) investigate several factors related to corruption level in many countries. Their results show that married individuals also tend to perceive lower level of corruption compared to divorced individuals because divorced individuals have negative impact in shaping judgments due to their miserable life. Hence, the effect of marital status is believed to have an influence on the misconduct of the individuals which later lead to corruption activities.

Seniority of LOE provides greater working experience that supposed to lead to the well verse of their task orientation. Factors, such as job tenure, secondment and training may have some impact to LOE integrity practices. Donner and Jennings (2014) examine the relationship between police misconduct and self-control attitude. The study found that low self-control on attitude and job tenure influence police misconduct. The study implies that long job tenure is positively related to the misconduct. Next, Akindele, Oginni, and Agada (2013) investigate the effect of unethical attitude practiced by leaders in Nigeria on national development. The study stated that recklessness and unfair attitudes of the leaders can affect youth development in the country. The study further explains that job tenure influences corruption practices and unethical actions of the leader in micro and macro level. Moreover, White and Kane (2013) examine career factor and police misconduct in New York City. The results show that the length of services is a predictor of misconduct and promotion only protects against early termination in a police officer's career 
Lepisto, Gisselquist, and Ojala (2015) discuss on embedding high-skilled personnel of local government agencies with secondment experiences in Somalia. They reveal that secondment contributes positive effect to fragile state and guide the country towards recovery. In addition, Igbokwe-Ibeto, Justine, and Agbodike (2015) examine the influence of secondment on employee performance in Nigerian civil service, and obtained insignificant result. The results further explain that transfer and secondment cannot guarantee productivity and performance of employee in Nigerian civil service. Porteous (2011) find that secondment of Polish police officers provides positive contributions to Metropolitan Police Service since the Polish police officers played important role in related police work and several investigations.

Training and education are believed to reduce the ethical misconduct and increase the individuals' quality and competency. The purpose of training is to change the mentality of the officers towards corruption (Kumssa, 2015, Bahrin, et.al 2018). Hauser and Hogenacker (2014), examined on corruption prevention related to Swiss firms. The findings show that firms do not analyse potential risks associated with corruption when dealing with any countries perceived to be of high corruption countries. The study further explains that consistent training of personnel can prevent corruption effectively and minimise the risk of corruption. Next, Chiekezie, Nzewi, and Emejulu (2016) analysed whether corruption is a major challenge that influence human capital development in Nigeria. The results show that corruption distorts human capital development and consequently disrupt the country in achieving national goals (Suryanto, Haseeb, \& Hartani, 2018).

Organisational factors, such as rank and salary would also affect LOE integrity. Sundstrom (2016) reveals that the process on how corruption problem arises in the Africa, involves higher ranks officers that contributes the negative influence to their subordinates. Previous studies show mixed results on whether salary influences corruption or not. According to Schulze, Sjahrir, and Zakharov (2016), higher salary may reduce corruption. Meanwhile, the study from Eitle, D'Alessio, and Stolzenberg (2014) reveals that salary level does not influence or reduce officers misconduct.

The level of salary commonly influences the corruption among individuals. The acts of corruption were triggered when the individuals feel that they are underpaid together with high workload burden. Eitle et al. (2014), Bhattarai \& Carter (2018) reveals that higher salary can motivate the individuals, reduce opportunity of misconduct and unwanted behaviour. This is supported by Schulze et al. (2016) who analysed corruption incidents in Russian region. The results indicate that corruption level is determined by salaries level of bureaucrats. When salaries increase, the corruption level will decrease.

\subsection{Fraud Diamond Theory}

There are several theories that explain on the occurrence of corruption. Fraud diamond theory is one of the theories that is related with corruption and integrity. The fraud diamond is the extension of the fraud triangle theory and it delivers similar information regarding fraud areas. Fraud diamond theory (FDT) was introduced by Wolfe and Hermanson (2004), which includes four factors of fraud which are incentive, opportunity, rationalisation and capability. FDT explains the factors that trigger fraudulent actions and helps to understand the vulnerability of fraud. According to Peltier-Rivest (2017), fraud diamond framework can help the organisation to prevent the corruption activities effectively as public always have many creative ways to perform fraudulent activities as they believe that they have the opportunity to do so.

The first element in the fraud diamond is incentive. According to Abdullahi and Mansor (2015), incentive refers to perceived pressure or motives that lead to misconduct behaviour. Pressures are stressed condition felt by individuals that force them to do something. Financial pressure is one of the reasons why individuals or organisations commit fraud (Hanim et al., 2017; Peltier-Rivest, 2017; Bocij,2018). Financial difficulty forces individuals to work hard in order to gain extra money in their life. However, when the individuals fail to meet their financial obligation in legal ways, they will try to get the money in unethical ways. In addition, business organisations also feel the pressure regarding financial situation.

The second element in fraud diamond is opportunity. Opportunity is referred as lack of effectiveness on organisation's governance system and internal control that give the chance to individuals to convict fraud activities (Hye \& Siddiqui 2010; Abdullahi \& Mansor, 2015). Normally, the organisation only focuses on the information system internal control such as accounting system security. However, the organisation pays less attention on physical monitoring and control of their personnel. Lack of activities overseeing may give freedom to the personnel in making decisions and could lead to opportunity for them to commit fraud. In addition, tight monitoring and overseeing personnel activities could limit the opportunity of corruption to take place. Integrity test is required and should be performed unexpectedly where the opportunity and condition to commit fraud seems to exist (Lukito, 2016; 
Bosupeng, M. 2018).

The third element in the fraud diamond theory is rationalisation. Rationalisation allows unethical individuals to view their illegal activities as acceptable (Ruankaew, 2016). Rationalisation refers to formulation of morally acceptable idea for an individual before committing the fraudulent activities (Hye Lau \& Tourres 2014; Abdullahi \& Mansor, 2015). Individuals who want to commit the fraud actually know that their action is against the ethical code of conduct. However, they still proceed to commit fraudulent activities because they feel confident that they will not get caught by anyone. Furthermore, rationalisation judgement influenced by work culture allows individuals to justify their attitude with an acceptable reasons (Hanim et al., 2017; Caifen, Hailun \& Rongrong 2018). Positive judgement ability must be possessed by individuals to ensure individuals can think correctly about whether what they are doing is right or not.

The fourth element of fraud diamond is capability. According to Ruankaew (2016), individual who possess a position within the organisation may have the ability to create fraud opportunity not possessed by others. Capability refers to the competency, skill and ability possessed by the individuals to participate with the fraudulent activities and turn it into reality (Abdullahi \& Mansor, 2015; Wolfe \& Hermanson, 2004). People who are very skillful in performing fraud have special capabilities to manipulate the fraudulent action to ensure that other people cannot detect their unethical activities. Officer position or seniority in the organisation will help the individuals to commit fraud as abused power influences their intention to commit fraud.

\subsection{Consequences of Corruption and Unethical Activities}

The public at large acknowledge that corruption could severely affect the country's economy and mislead accounting information. Corruption may affect many parties. Firstly, bad corruption perception index may slow down the economic growth of the country, especially regarding the foreign direct investment aspect. The countries with higher corruption perception index can negatively affect the volume of foreign direct investment (Godinez \& Liu, 2015). According to Qian, Sandoval-Hernandez, and Garrett (2016), the distinction in corruption levels between countries could influence foreign direct investment inflow into the countries. Consequently, corruption can deter the country's reputation and create barrier to the foreign direct investment.

Secondly, corruption activities may affect government's budget allocation plan since they had caused inefficient allocation of budget that resulted to high government expenditure cost. According to Liu and Mikesell (2014), bribery attitude practiced by the government officers is the main problem failing the proper allocation of public resources. The government officers manipulate the costs so that they can receive huge budget allocation (Ajlouni, 2017). Public become victims when they do not receive appropriate benefits from the budget allocation. The money is not properly channelled to the specific areas and negatively affects social development. Moreover, budgeting problems become worse when the government face budget deficit and need extra money to cover up the deficit (Hye \& Lau 2015; Jermsittiparsert, 2016).

Thirdly, lack of integrity of individuals or organisation could lead to tax evasion problems. Tax evasion frequently happens in many countries because of individuals' unethical attitudes. The government losses billions in tax revenue that could be beneficial for country's development. According to Ajlouni (2017), tax evasion is done through falsification of documents done by the authorised officer to deceive the tax authority.

Finally, unethical individuals are more likely to misuse organisation's assets for their self-interest. Misappropriation of assets can distort the smoothness of the organisation to run their daily operation and can affect the public funds. Based on the findings from Hanim et al. (2017), integrity has negative relationship with the misappropriation of assets. In most cases, people are not seriously committed to fight the fraudulent activity because integrity is not emphasised in their vision, mission and policy statements (Majid, Basri, Mohamed, \& Ahmad, 2016).

\section{Methodology}

\subsection{Census and Data Collection}

The total population of local enforcement officers registered under Setiausaha Kerajaan (SUK) Selangor as at June 2017 is 2,391 officers.

This study has chosen PULAPES as a place to distribute the questionnaire survey. PULAPES is the main training centre governed by SUK Selangor to enhance their local enforcement officers' skill and competency. Furthermore, the selection of PULAPES as a place to distribute the questionnaire is very effective as most local enforcement officers gather there during the training session. The questionnaires were distributed to these local enforcement officers during four series of training which was held on August to October 2017. The respondents were given 30 
minutes to answer the questionnaire. The total respondents in this study consist of 216 local enforcement officers across four training series. All of the respondents answered and returned the questionnaires during the training sessions. According to Roscoe (1975), based on rules of thumb condition, the sample size at range 30 to 500 is appropriate for most research. As the total respondents collected in this study is 216 (out of 2,391) satisfies the rule of thumb condition.

\subsection{Questionnaire Development}

The questionnaire is designed to measure all independent and dependant variables examined in this study. The questionnaire was adapted from Klockars, Ivkovich, Harver, and Haberfeld (2000) with minimal modification to fit with the local enforcement environment in Malaysian perspective. Despite of long establishment period of usage, the same questionnaire still be used until now with few necessary modification (Ivkovic \& Sauerman, 2016; Lim \& Sloan, 2016; Lobnikar et al., 2016). It shows that the questionnaire still relevant, reliable and valid in measuring the integrity level.

The questionnaire set is divided into two sections, namely section A and section B. Section A of the questionnaire measures the demographic, experience and organisational factors. The respond formats of the questionnaire consist of both open-ended and closed-ended questions. Section B of the questionnaire measures the integrity level of enforcement officers using Likert scale. 11 scenario-based questions called "Case" regarding the local government officers' misconduct (Ahmed, Khalid, Ammar \& Shah, 2017).

Four cases had been modified from the original questionnaires, which are Case 3, 5, 8 and 10. The modification is done upon verbal discussion with PULAPES's officer to suit the working environment of the local enforcement officers. Case 3 had been changed to 'bribery received from dirty shop owner' instead of 'bribery received from the speeding motorist'. In Case 5, the case had been changed to 'the officer stole the pirate CD/DVD during official investigation' instead of 'the officer stole the watches at the burglary incident'. While in Case 8, the case had been changed to 'the officer on duty has not reported colleague officer convicted during raid in the unlicensed entertainment centre' instead of 'the officer on duty has not reported the accident involved by intoxicated colleague officer'. Finally, Case 10 had been changed to 'the culprit has been punched by the officer when escaped from illegal gambling premise raid' instead 'the culprit has been punched by the officer after broke the automobile'.

\subsection{Variables}

In experience factors category, there are three variables; which are job tenure, training and secondment. Job tenure and training is measured as ordinal. Job tenure is measured as "1" less than 5 years, "2" 5 to 8 years, " 3 " 9 to 14 years, " 4 " 15 to 20 years, and " 5 " more than 20 years. Training is measured as " 1 " 1 to 7 days, " 2 " 8 to 10 days, " 3 " 11 to 14 days, and " 4 " 15 to 20 days. Secondment is measured as dichotomous, which are "yes" and "no".

In organisational factors category, there are two variables; which are officer rank and salary. Both variables are measured as ordinal. Officer rank is measured as "1" enforcement assistant, "2" senior enforcement assistant, "3" high level senior enforcement assistant, "4" assistant enforcement officer, "5" senior assistant enforcement officer, "6" enforcement officer, "7" senior enforcement officer, and " 8 " enforcement director. Salary is measured as " 1 " RM900- RM1,499, "2" RM1,500 to RM2499, “3” RM2500 to RM3499, “4” RM3500 to RM4499, and "5” RM4500 and above.

This study use Cronbach's Alpha to determine the reliability of the data. In this study, the value of Cronbach's Alpha for integrity local enforcement officers is 0.92 with 44 total items. The results show the reliability of data is categorised as excellent. The study used skewness and kurtosis to determine the normality of data. The normality results show that the total score for local enforcement officers' integrity for both self-proclaim and colleague perception are normally distributed. According to Kline (1998), the data is normally distributed when the skewness value is \pm 3 and kurtosis is \pm 10 . Table 1 shows the normality tests that been conducted:

Table 1 . Test of normality

\begin{tabular}{lllll}
\hline & Skewness & \multicolumn{3}{l}{ Kurtosis } \\
\cline { 2 - 5 } & Statistic & Std. Error & Statistic & Std. Error \\
\hline Integrity - self proclaim & -.413 & .166 & 1.028 & .330 \\
\hline Integrity - colleague perception & -.945 & .116 & 3.150 & .330 \\
\hline
\end{tabular}


The study conducts paired-samples t-test analysis to determine the significant difference between two means of self-proclaim and colleague perception.

\section{Empirical Results and Discussion}

\subsection{Descriptive Results}

Table 2 shows the details of respondents for each independent variable in this study. For gender, the study is dominated by males; consisting of 203 respondents which represents $94 \%$ of respondents and followed by $6 \%$ female. For marital status factor, $66.2 \%$ of the respondents are married while only some of them $(0.9 \%)$ are divorced. Under job tenure factor, majority of the local enforcement officers (57.9\%) have been serving the local authority for less than five years tenure and only $1.9 \%$ of them have served more than 20 years. As for secondment factor, $95.8 \%$ of the respondents have never been involved in secondment as compared to only $4.2 \%$ of those who have involved in secondment.

For training factor, $63 \%$ of the respondents have attended short-term training (1-7 days) and only $4.6 \%$ have attended long-term training (15-20 days). For officer rank factor, assistant enforcement dominated $92.6 \%$ as compared to the other ranks, with the lowest being senior enforcement officer $(0.9 \%)$. Lastly, for salary factor, $48.6 \%$ of the respondents are in the category of those receiving salary in the range between RM1,500 - RM2,499 while only 1\% of them are in the category of salary in the range between RM3,500 to RM4,499.

Table 2. Descriptive statistics

\begin{tabular}{|c|c|c|c|c|}
\hline Variables & $\mathrm{N}$ & Percentage (\%) & Mean & Std. Dev. \\
\hline \multicolumn{5}{|l|}{ Gender } \\
\hline Male & 203 & 94 & & \\
\hline Female & 13 & 6 & & \\
\hline Total & 216 & 100 & 1.06 & 0.24 \\
\hline \multicolumn{5}{|l|}{ Marital status } \\
\hline Married & 143 & 66.2 & & \\
\hline Single & 71 & 32.9 & & \\
\hline Divorced & 2 & 0.9 & & \\
\hline Total & 216 & 100 & 1.35 & 0.50 \\
\hline \multicolumn{5}{|l|}{ Job tenure } \\
\hline Less than 5 years & 125 & 57.9 & & \\
\hline $5-8$ years & 24 & 11.1 & & \\
\hline $9-14$ years & 34 & 15.7 & & \\
\hline $15-20$ years & 29 & 13.4 & & \\
\hline Above 20 years & 4 & 1.9 & & \\
\hline Total & 216 & 100 & 1.90 & 1.20 \\
\hline \multicolumn{5}{|l|}{ Secondment } \\
\hline No & 207 & 95.8 & & \\
\hline Yes & 9 & 4.2 & & \\
\hline Total & 216 & 100 & 1.04 & 0.20 \\
\hline \multicolumn{5}{|l|}{ Training } \\
\hline 1 - 7 days & 136 & 63 & & \\
\hline 8 - 10 days & 46 & 21.3 & & \\
\hline 11 - 14 days & 24 & 11.1 & & \\
\hline
\end{tabular}




\begin{tabular}{lllll}
\hline 15 - 20 days & 10 & 4.6 & 1.57 & 0.87 \\
\hline Total & 216 & 100 & & \\
\hline Officer rank & & & & \\
\hline Assistant enforcement & 200 & 92.6 & & \\
\hline Senior assistant enforcement & 10 & 4.6 & & \\
\hline Assistant enforcement officer & 3 & 1.4 & & \\
\hline Senior enforcement officer & 1 & 0.5 & & \\
\hline Director of enforcement officer & 2 & 0.9 & & \\
\hline Total & 216 & 100 & & \\
\hline Salary & & & & \\
\hline RM900 - RM1,499 & 64 & 29.6 & & \\
\hline RM1,500 - RM2,499 & 105 & 48.6 & & \\
\hline RM2,500 - RM3,499 & 40 & 18.5 & & \\
\hline RM3,500 - RM4,499 & 2 & 1 & & \\
\hline Above RM4,500 & 5 & 2.3 & & \\
\hline Total & 216 & 100 & & \\
\hline
\end{tabular}

\subsection{Integrity Level - Offence Seriousness and Willingness to Report}

This section explains the integrity level of local enforcement officers which focuses on offence seriousness and willingness to report. Both offence seriousness and willingness to report were specifically grouped into two main perspectives, namely self-proclaim and colleague perception. Each case was ranked based on cases' mean value and labelled with the number accordingly. In classifying the rank of each cases, the study used a parameter based on the Likert scale value used to measure the integrity level in the questionnaire. In Likert scale measurement, the case is classified as "not serious" when the mean value is $<4$ and is classified as "serious" when the mean value is $\geq 4$.

Table 3 shows the results on integrity level of local enforcement officers in offence seriousness. In self-proclaim perspective, Case $3(\mathrm{M}=4.73)$, Case $9(\mathrm{M}=4.59)$, Case $5(\mathrm{M}=4.38)$, Case $8(\mathrm{M}=4.24)$ and Case $11(\mathrm{M}=4.23)$ are classified as serious while the rest of the cases are classified as not serious. Case 3 is ranked as the highest in offence seriousness category compared to the others in self-proclaim perspective while Case $1(\mathrm{M}=2.17)$ is ranked as the lowest.

Next, in colleague perception perspective, Case $3(M=4.61)$, Case $9(M=4.54)$, Case $5(M=4.44)$, Case $8(M=$ 4.23) and Case $11(\mathrm{M}=4.14)$ are classified as serious while the rest of the cases are classified as not serious. Case 3 was ranked as the highest in offence seriousness category compared to the others in colleague perception perspective while Case $1(\mathrm{M}=2.25)$ is ranked as the lowest. In ranking position, both self-proclaim and colleague perception have are recorded to be in the same position under offence seriousness category with different mean values.

Table 3. Local enforcement officers' integrity level - offence seriousness

\begin{tabular}{|c|c|c|c|c|c|c|}
\hline & \multicolumn{6}{|c|}{ Offence seriousness } \\
\hline & \multicolumn{3}{|c|}{ Self-proclaim } & \multicolumn{3}{|c|}{ Colleague perception } \\
\hline Ranks & Cases & Mean & Classifications & Case & Mean & Classifications \\
\hline 1 & 3 & 4.73 & Serious & 3 & 4.61 & Serious \\
\hline 2 & 9 & 4.59 & Serious & 9 & 4.54 & Serious \\
\hline 3 & 5 & 4.38 & Serious & 5 & 4.44 & Serious \\
\hline 4 & 8 & 4.24 & Serious & 8 & 4.23 & Serious \\
\hline
\end{tabular}




\begin{tabular}{lllllll}
\hline 5 & 11 & 4.23 & Serious & 11 & 4.14 & Serious \\
\hline 6 & 7 & 3.94 & Not serious & 7 & 3.96 & Not serious \\
\hline 7 & 10 & 3.62 & Not serious & 10 & 3.6 & Not serious \\
\hline 8 & 4 & 3.54 & Not serious & 4 & 3.53 & Not serious \\
\hline 9 & 2 & 3.08 & Not serious & 2 & 3.2 & Not serious \\
\hline 10 & 6 & 2.7 & Not serious & 6 & 2.85 & Not serious \\
\hline 11 & 1 & 2.17 & Not serious & 1 & 2.25 & Not serious
\end{tabular}

Notes: Case 1: Off-duty security system business, Case 2: Free meals on beat, Case 3: Bribe from dirty shop, Case 4: Gifts from merchants, Case 5: Theft of pirate CD/DVD during official duty, Case 6: Auto repair shop 5\% kickback, Case 7: Holiday for tune-up superior personal car, Case 8: Cover-up of convicted officer during raid, Case 9: Drank alcoholic drinks and ignore late bar closing, Case 10: Excessive force on culprit, Case 11: Theft from found wallet.

Table 4 shows the results on integrity level of local enforcement officers in willingness to report. In Likert scale measurement, the case is classified as "unlikely to report" when the mean value is $<4$ and is classified as "likely to report" when the mean value is $\geq 4$. In self-proclaim perspective, Case $9(\mathrm{M}=4.22)$ and Case $8(\mathrm{M}=4)$ are classified as likely to report while the rest are classified as unlikely to report. Case 9 is ranked as the highest in willingness to report category compared to the other cases in self-proclaim perspective while Case 1 is ranked as the lowest.

Next, in colleague perception perspective, only Case $9(\mathrm{M}=4.16)$ is classified as likely to report while the rest are classified as unlikely to report. Case 9 is ranked as the highest in willingness to report category compared to the other cases under colleague perception perspective while Case $1(\mathrm{M}=2.26)$ is ranked as the lowest.

Table 错误!文档中没有指定样式的文字。. Local enforcement officers' integrity level - Willingness to report

\begin{tabular}{|c|c|c|c|c|c|c|}
\hline \multirow[b]{3}{*}{ Ranks } & \multicolumn{6}{|c|}{ Willingness to report } \\
\hline & \multicolumn{3}{|c|}{ Self-proclaim } & \multicolumn{3}{|c|}{ Colleague perception } \\
\hline & Cases & Mean & Classifications & Cases & Mean & Classifications \\
\hline 1 & 9 & 4.22 & Likely to report & 9 & 4.16 & Likely to report \\
\hline 2 & 8 & 4 & Likely to report & 8 & 3.99 & Unlikely to report \\
\hline 3 & 3 & 3.93 & Unlikely to report & 3 & 3.93 & Unlikely to report \\
\hline 4 & 5 & 3.75 & Unlikely to report & 5 & 3.73 & Unlikely to report \\
\hline 5 & 11 & 3.66 & Unlikely to report & 11 & 3.7 & Unlikely to report \\
\hline 6 & 7 & 3.62 & Unlikely to report & 7 & 3.7 & Unlikely to report \\
\hline 7 & 10 & 3.2 & Unlikely to report & 10 & 3.34 & Unlikely to report \\
\hline 8 & 4 & 3.06 & Unlikely to report & 4 & 3.2 & Unlikely to report \\
\hline 9 & 2 & 2.73 & Unlikely to report & 2 & 2.91 & Unlikely to report \\
\hline 10 & 6 & 2.54 & Unlikely to report & 6 & 2.82 & Unlikely to report \\
\hline 11 & 1 & 1.83 & Unlikely to report & 1 & 2.26 & Unlikely to report \\
\hline
\end{tabular}

Notes: Case 1: Off-duty security system business, Case 2: Free meals on beat, Case 3: Bribe from dirty shop, Case 4: Gifts from merchants, Case 5: Theft of pirate CD/DVD during official duty, Case 6: Auto repair shop 5\% kickback, Case 7: Holiday for tune-up superior personal car, Case 8: Cover-up of convicted officer during raid, Case 9: Drank alcoholic drinks and ignore late bar closing, Case 10: Excessive force on culprit, Case 11: Theft from found wallet

\subsection{Integrity Level - Violation Agency's Policy and Disciplinary Mode}

This section explains the integrity level of local enforcement officers which focuses on the violation of agency's 
policy and disciplinary mode. Table 5 and Table 6 show the results of local enforcement officers' integrity level under violation of agency's policy and disciplinary mode. The results explained the integrity level of local enforcement officers in general and did not specifically focus on self-proclaim or colleague perception perspectives. Each case was ranked based on cases' mean value and labelled accordingly with numbers. Both violation agency's policy and disciplinary mode are explained based on the Likert scale measurement in the questionnaire. In violation of agency's policy category, the case is classified "low violation" when the mean value $<4$ while, and when the mean value is $\geq 4$ it is classified as "high violation". In disciplinary mode, the case is classified as "none" when the mean value is $<2$, "verbal reprimand" when the mean value $\geq 2$ to $<3$, "written reprimand" when the mean value $\geq 3$ to $<4$, "period suspension without pay" when the mean value $\geq 4$ to $<5$, "demotion in rank" when the mean value $\geq$ 5 to $<6$ and "dismissal" when the mean value $\geq 6$.

Table 5 shows the results of local enforcement officers' integrity level under violation of agency's policy. In violation of agency's policy, Case $3(\mathrm{M}=4.67)$, Case $9(\mathrm{M}=4.56)$, Case $5(\mathrm{M}=4.43)$, Case $8(\mathrm{M}=4.32)$ and Case $11(\mathrm{M}=4.21)$ are classified as high violation on agency's policy while the rest of cases are classified as low violation on agency's policy. Case 3 is ranked as the highest in violation agency's policy category compared to the other cases while Case $1(\mathrm{M}=1.96)$ was ranked as the lowest rated by the respondents.

Table 5. Local enforcement officers' integrity level - violation agency's policy

\begin{tabular}{llll}
\hline Ranks & Cases & Mean & Classifications \\
\hline 1 & 3 & 4.67 & High violation \\
\hline 2 & 9 & 4.56 & High violation \\
\hline 3 & 5 & 4.43 & High violation \\
\hline 4 & 8 & 4.32 & High violation \\
\hline 5 & 11 & 4.21 & High violation \\
\hline 6 & 7 & 3.9 & Low violation \\
\hline 7 & 10 & 3.73 & Low violation \\
\hline 8 & 2 & 3.61 & Low violation \\
\hline 9 & 4 & 3.28 & Low violation \\
\hline 10 & 6 & 2.77 & Low violation \\
\hline 11 & 1 & 1.96 & Low violation \\
\hline
\end{tabular}

Notes: Case 1: Off-duty security system business, Case 2: Free meals on beat, Case 3: Bribe from dirty shop, Case 4: Gifts from merchants, Case 5: Theft of pirate CD/DVD during official duty, Case 6: Auto repair shop 5\% kickback, Case 7: Holiday for tune-up superior personal car, Case 8: Cover-up of convicted officer during raid, Case 9: Drank alcoholic drinks and ignore late bar closing, Case 10: Excessive force on culprit, Case 11: Theft from found wallet

Table 6 shows the results of local enforcement officers' integrity level under disciplinary mode. In disciplinary mode category, Case 9 and 8 are classified as "Suspension without pay", Case 3, 5, 7 and 11 is classified as "Written reprimand", Case 10, 4, 2 and 6 is classified as "Verbal reprimand" and only Case 1 is classified as "No action'. The Case 9 was ranked as the severest discipline mode of punishment in the local enforcement agency while Case 1 has ranked as the lightest punishment action rated by the respondents

Table 6. Local enforcement officers' integrity level - disciplinary mode

\begin{tabular}{llll}
\hline Ranks & Cases & Mean & Classifications \\
\hline 1 & 9 & 4.31 & Suspension without pay \\
\hline 2 & 8 & 4.07 & Suspension without pay \\
\hline 3 & 3 & 3.83 & Written reprimand \\
\hline
\end{tabular}




\begin{tabular}{llll}
\hline 4 & 5 & 3.57 & Written reprimand \\
\hline 5 & 7 & 3.41 & Written reprimand \\
\hline 6 & 11 & 3.2 & Written reprimand \\
\hline 7 & 10 & 2.79 & Verbal reprimand \\
\hline 8 & 4 & 2.45 & Verbal reprimand \\
\hline 9 & 2 & 2.39 & Verbal reprimand \\
\hline 10 & 6 & 2.19 & Verbal reprimand \\
\hline 11 & 1 & 1.88 & No action
\end{tabular}

Notes: Case 1: Off-duty security system business, Case 2: Free meals on beat, Case 3: Bribe from dirty shop, Case 4: Gifts from merchants, Case 5: Theft of pirate CD/DVD during official duty, Case 6: Auto repair shop 5\% kickback, Case 7: Holiday for tune-up superior personal car, Case 8: Cover-up of convicted officer during raid, Case 9: Drank alcoholic drinks and ignore late bar closing, Case 10: Excessive force on culprit, Case 11: Theft from found wallet

\subsection{Paired-Samples T-test Analysis}

In this section, paired samples t-test compares the difference between mean value from both self-proclaim and colleague perception perspectives. Mean value of both self-proclaim and colleague perception are measured based on total scores of Likert scale. Table 7 shows the results of paired samples t-test. There are two main categories to be focused, which are offence seriousness and willingness to report. In offence seriousness category, there is no significant difference between self-proclaim $(\mathrm{M}=41.20)$ and colleague perception $(\mathrm{M}=41.35), t=-.661$ and $p$ $=.510$ which is greater than .05 . It means integrity level in self-proclaim perspective does not show any difference with the integrity level in colleague perception perspective when measured under offence seriousness category. Next, in willingness to report category, there is a significant difference between self-proclaim $(M=36.54)$ and colleague perception ( $\mathrm{M}=37.74), t=-2.386$ and $p=.018$ which is less than .05 . The results imply that the integrity level both from self-proclaim and colleague perception perspectives shows significant difference when measured under the category of willingness to report. Furthermore, in willingness to report, colleague perception has higher integrity level based on mean value compared to self-proclaim. The higher the mean value, the more likely of local enforcement officers will report misconduct.

Table 7. Paired-samples t-test

\begin{tabular}{lllll}
\hline & \multicolumn{2}{l}{ Offence seriousness } & \multicolumn{2}{l}{ Willingness to report } \\
\hline & $\mathrm{t}$-value & $\mathrm{p}$-value & $\mathrm{t}$-value & $\mathrm{p}$-value \\
\hline Self-proclaim - colleague perception & -.661 & .510 & -2.386 & $.018^{*}$ \\
\hline
\end{tabular}

*Correlation is significant at the 0.05 level

\section{Conclusion}

Local enforcement authorities need high ethical behaviour personnel to enhance their service quality in serving the public. Negative external pressure in local enforcement officers working environment demands the organisation to have personnel who possess high integrity level to handle any situation appropriately. Therefore, this study aims to analyse whether demographic, experience and organisational factors can influence the integrity level of local enforcement officers.

From the results of paired samples t-test of both self-proclaim and colleague perception perspectives, this study concludes that the integrity level from self-proclaim and colleague perception perspectives shows significant difference only when measured under the category of willingness of LOE to report. Furthermore, in this category, colleague perception has higher integrity level based on mean value compared to self-proclaim.

Corruption issues are synonym to the government servants who are vulnerable to the opportunity of being unethical as integrity plays an important role to mitigate corruption problems faced. Risk on taking bribe and abuses of power can lower the credibility of the enforcement officer. Enforcement officer, frequently faces coercive pressure from 
many parties who want to fulfil their illegal personal interest. These pressures must be taken care correctly to avoid any discredit on enforcement organisation profession.

\section{References}

Abdullahi, R., \& Mansor, N. (2015). Fraud triangle theory and fraud diamond theory. Understanding the convergent and divergent for future research. International Journal of Academic Research in Accounting, Finance and Management Sciences, 5(4), 38-45. https://doi.org/10.6007/IJARAFMS/v5-i4/1823

Adamowicz, M., \& Machla, A. (2016). Small and Medium Enterprises and the Support Policy of Local Government. Oeconomia Copernicana, 7(3), 405-437. https://doi.org/10.12775/OeC.2016.024

Ahmed, U., Khalid, N., Ammar, A., \& Shah, M. H. (2017). Assessing moderation of employee engagement on the relationship between work discretion, job clarity and business performance in the banking sector of Pakistan. Asian Economic and Financial Review, 7(12), 1197-121.

Ajlouni, M. T. (2017). Integrity and corruption in the health sector in Jordan: The perceptions of leaders of Non-Government Health Organizations (NGHOs). International Business Research, 10(2), 95-103.

Akindele, R. I., Oginni, B. O., \& Agada, S. A. (2013). National development and political corruption in Nigeria: Leadership at crossroad. European Journal of Business and Management, 5(9), 170-179.

Atkinson, A.B., \& Stiglitz, J.E. (1980). Lectures on Public Economics. London, McGraw Hill.

Ayyagari, M., Beck, T., \& Demirguc-kunt, A. (2007). Small and medium enterprises across the globe. Small Business Economics, 29, 415-434. https://doi.org/10.1007/s11187-006-9002-5

Bahrin, F. K., Azman, A., Zainol, I. N. H., Yusof, M. M., \& Shaed, M. M. (2018). The Level of Knowledge of Secondary School Students in Penang About HIV/AIDS: Pre and Post Intervention. International Journal of Asian Social Science, 8(8), 540-548. https://doi.org/10.18488/journal.1.2018.88.540.548

Beck, T., Demirguc-Kunt, A., \& Martinez Peira, M. S. (2011). Bank financing for SMEs: evidence across countries and bank ownership types. Journal of Financial Services Research, 39, 35-54.

Berger, A. N., \& Udell, G. F. (2002). Small business credit availability and relationship lending: the importance of bank organizational structure. The Economic Journal, 112(477), 32-53.

Berger, A. N., Goldberg, L. G., \& White, L. J. (2001a). The effects of dynamic changes in bank competition on the supply of small business credit. European Financial Review, 5, 115-139.

Berger, A. N., Klapper, L. F., \& Udell, G. F. (2001b). The ability of banks to lend to informationally opaque small business. Journal of Banking and Finance, 25, 2127-2167. https://doi.org/10.1016/S0378-4266(01)00189-3

Berger, A. N., Klapper, L. F., Martinez-Peria, M. S., \& Zaidi. R. (2008). Bank ownership and banking Relationships. Journal of Financial Intermediation, 17, 37-62. https://doi.org/10.1016/j.jfi.2006.11.001

Bhattarai, K., \& Carter, M. (2018). An Empirical Analysis of the Taylor Rule and its Application to Monetary Policy: A Case for the United Kingdom and Euro Area. Asian Journal of Economics and Empirical Research, 5(2), 173-182. https://doi.org/10.20448/journal.501.2018.52.173.182

Bocij, P. (2018). OVIAR: Towards a Model for Cyberstalking Intervention and Reduction. International Journal of Emerging Trends in Social Sciences, 4(2), 58-66. https://doi.org/10.20448/2001.42.58.66

Bosupeng, M. (2018). Leading Indicators and Financial Crisis: A Multi-Sectoral Approach Using Signal Extraction. Journal of Empirical Studies, 5(1), 20-44. https://doi.org/10.18488/journal.66.2018.51.20.44

Caifen, W., Hailun, F., \& Rongrong, C. (2018). The Research on Graduate Students' Understanding of Three Basic Limit Concepts. American Journal of Education and Learning, 3(2), 100-107.

Chang, C., Liao, G., Yu, X., \& Ni, Z. (2014). Information from lending relationship: evidence from loan defaults in China. Journal of Money, Credit and Banking, 46(6), 1225-1257. https://doi.org/10.1111/jmcb.12139

Chatterjee, I., \& Ray, R. (2014). Crime, corruption and the role of institutions. Indian Growth and Development Review, 7(1), 73-95. https://doi.org/10.1108/IGDR-11-2011-0040

Chiekezie, O. M., Nzewi, N. H., \& Emejulu, G. A. (2016). Corruption as a major challenge of human capital development in Nigeria. International Journal of Management and Economics Invention, 2(5), 601-608.

Clarke, G., Cull, R., Martinez Peria, M.S., \& Sanchez, S.M., (2005). Bank lending to small business in Latin America: Does bank origin matter?. Journal of Banking Money, Credit, and Banking, 37, 83-118.

D’Aurizio, L., Oliveiro, T., \& Romano, L. (2015). Family firms, soft information and bank lending in a financial 
crisis. Journal of Corporate Finance, 33, 279-292. https://doi.org/10.1016/j.jcorpfin.2015.01.002

Detragiache, E., Tressel, T., \& Gupta, P. (2006). Foreign banks in poor countries: Theory and evidence. IMF Working Paper No. 18. International Monetary Fund, Washington DC.

Dolezal, J., Snajdr, J., Belas, J., \& Vincurova, Z. (2015). Model of the loan process in the context of unrealized income and loss prevention. Journal of International Studies, 8(1), 91-106.

Donner, C. M., \& Jennings, W. G. (2014). Low self-control and police deviance: Applying Gottfredson and Hirschi's general theory to officer misconduct. Police Quarterly, 17(3), 203-225.

Dubravska, M., Mura, L., Kotulic, R., \& Novotny, J. (2015). Internationalization of Entrepreneurship-Motivating Factors: Case Study of the Slovak Republic. Acta Polytechnica Hungarica, 12(5), 121-133.

Eitle, D., D'Alessio, S. J., \& Stolzenberg, L. (2014). The effect of organizational and environmental factors on police misconduct. Police Quarterly, 17(2), 103-126. https://doi.org/10.1177/1098611114522042

Fiserova, T., Teply, P., \& Tripe, D. (2015). The performance of foreign-owned banks in the host country economics. Prague Economic Papers, 24(5), 1-24. https://doi.org/10.18267/j.pep.527

Godinez, J. R., \& Liu, L. (2015). Corruption distance and FDI flows into Latin America. International Business Review, 24, 33-42. https://doi.org/10.1016/j.ibusrev.2014.05.006

Goel, R. K., Mazhar, U., \& Nelson, M. A. (2014). Corruption across government occupations: Cross-national survey evidence. Journal of International Development, 28(8), 1220-1234. https://doi.org/10.1002/jid.3040

Gormley, S., Kanatas, G., \& Venezia, I. (2006). Bank competition in developing countries: does foreign bank entry improve credit access? Mimeo. MIT.

Hanim, H., Bakri, M., Mohamed, N., \& Said, J. (2017). Mitigating asset misappropriation through integrity and fraud risk elements: Evidence emerging economies. Journal of Financial Crime, 24(2), 242-255.

Hauser, C., \& Hogenacker, J. (2014). Do firms proactively take measures to prevent corruption in their international operations. European Management Review, 11, 223-237. https://doi.org/10.1111/emre.12035

Hickman, M. J., Piquero, A. R., Powell, Z. A., \& Greene, J. (2016). Expanding the measurement of police integrity. Policing: An International Journal of Police Strategies \& Management, 39(2), 246-267.

Hye, Q. M. A., \& Lau, W. Y. (2015). Trade openness and economic growth: empirical evidence from India. Journal of Business Economics and Management, 16(1), 188-205. https://doi.org/10.3846/16111699.2012.720587

Hye, Q. M. A., \& Siddiqui, M. M. (2010). Economic growth and management of natural resources in the case of Pakistan. European Journal of Economics, Finance and Administrative Sciences, (22).

Hye, Q. M. A., Lau, W. Y., \& Tourres, M. A. (2014). Does economic liberalization promote economic growth in Pakistan? An empirical analysis. Quality \& Quantity, 48(4), 2097-2119.

Igbokwe-Ibeto, Justine, C., \& Agbodike, F. (2015). Recruitment policies in the Nigerian federal civil service and their implications on employees' performance. Kuwait Chapter of Arabian Journal of Business and Management Review, 5(3), 34-48. https://doi.org/10.12816/0019014

Ikezue, C. E., \& Alawari, M. B. (2015). Public perception of corruption in anambra state: A study of Aguata local government area. Journal of Religion and Human Relations, 7(1), 130-142.

Ivkovic, S. K., \& Sauerman, A. (2016). Police integrity in South Africa: A tale of three police agency types. Policing: An International Journal of Police Strategies \& Management, 39(2), 268-283.

Jermsittiparsert, K. (2016). Culture of 'Elephant front legs-hind legs': A debate on the actuality of sexual politics in Thai society. The Social Sciences, 11(1), 20-28.

Jimenez, G., Salas, V., \& Saurina, J. (2006). Determinants of collateral. Journal of Financial Economics, 81, 255-281. https://doi.org/10.1016/j.jfineco.2005.06.003

Kline, R. B. (1998). Principles and practices of structural equation modeling. New York: Guilford.

Kljucnikov A., Belas, J., Kozubikova, L., \& Pasekova P. (2016).The Entrepreneurial Perception of SME Business Environment Quality in the Czech Republic. Journal of Competitiveness, 8(1), 66-78.

Klockars, C. B., Ivkovich, S. K., Harver, W. E., \& Haberfeld, M. R. (2000). The measurement of police integrity. National Institute of Justice Research in Brief. Retrieved from https://www.ncjrs.gov/pdffiles1/nij/181465.pdf

Kumssa, A. (2015). Police corruption: A perspective on its nature and control. Donnish Journal of Political Science and International Relations, 1(1), 1-8. 
La Porta, R., Lopez-de-Silances, F., \& Shleifer, A. (2002). Government ownership of commercial banks. Journal of Finance, 57(1), 265-301. https://doi.org/10.1111/1540-6261.00422

Lepisto, R. S., Gisselquist, R. M., \& Ojala, J. (2015). 'Embedded' Assistance: Finn church aid's secondment in Somalia. International Peacekeeping, 22(4), 354-371. https://doi.org/10.1080/13533312.2015.1059283

Lim, H., \& Sloan, J. J. (2016). Police officer integrity: A partial replication and extension. Policing: An International Journal of Police Strategies \& Management, 39(2), 284-301. https://doi.org/10.1108/PIJPSM-10-2015-0127

Liu, C., \& Mikesell, J. L. (2014). The impact of public officials' corruption on the size and allocation of U.S. state spending. Public Administration Review, 74(3), 346-359. https://doi.org/10.1111/puar.12212

Lobnikar, B., Prislan, K., Cuvan, B., \& Mesko, G. (2016). The code of silence and female police officers in Slovenia: Gender differences in willingness to report police misconduct. Policing: An International Journal of Police Strategies \& Management, 39(2), 387-400. https://doi.org/10.1108/PIJPSM-10-2015-0118

Lukito, A. S. (2016). Building anti-corruption compliance through national integrity system in Indonesia: A way to fight against corruption. Journal of Financial Crime, 23(4), 932-947. https://doi.org/10.1108/JFC-09-2015-0054

Majid, R. A., Basri, S. A., Mohamed, N., \& Ahmad, K. (2016). The commitment of local authorities in building fortress against misappropriation of assets. Malaysian Accounting Review, 15(2), 231-241.

Menkhoff, L., Neuberger, D., \& Rungruxsirivorn, O. (2012). Collateral and its substitutes in emerging markets lending. Journal of Banking and Finance, 36, 817-834. https://doi.org/10.1016/j.jbankfin.2011.09.010

Mesticka, K., \& Cabelkova, I. (2015). The relation of corruption perceptions, conformity and traditionalism: Macroeconomic study of 52 countries. Mediterranean Journal of Social Sciences, 6(5), 15-23.

Mian, A. (2003). Foreign, private domestic, and government banks: New evidence from emerging markets. University of Chicago, Mimeo.

Mian, A. (2006). Distance constraints: the limits of foreign lending in poor economics. Journal of Finance, 61(3), 1465-1505. https://doi.org/10.1111/j.1540-6261.2006.00878.x

Nguyen, S., \& Wolfee, S. (2016). Determinants of successful access to bank loans by Vietnamese SMEs: new evidence from the red river delta. Journal of Internet Banking and Commerce, 21(1), 1-23.

Peltier-Rivest, D. (2017). The prevention and detection of corruption in pharmaceutical companies. Pharmaceuticals Policy and Law, 19, 17-31. https://doi.org/10.3233/PPL-170451

Porteous, D. (2011). Good cop, Polish cop: Findings from an evaluation of the secondment of two Polish police officers to work with the metropolitan police service. Safer Communities, 10(2), 32-41. https://doi.org/10.5042/sc.2011.0184

Qian, X., Sandoval-Hernandez, J., \& Garrett, J. Z. (2016). Corruption distance and foreign direct investment. Emerging Markets Finance and Trade, 52(2), 400-419. https://doi.org/10.1080/1540496X.2015.1047301

Roscoe, J. T. (1975). Fundamental Research Statistics for the Behavorial Sciences (2nd ed.). New York: Holt, Rinehart and Winston.

Ruankaew, T. (2016). Beyond the fraud diamond. Intenational Journal of Business Management \& Economic Research, 7(1), 474-476.

Schulze, G. G., Sjahrir, B. S., \& Zakharov, N. (2016). Corruption in Russia. The Journal of Law and Economics, 59(1), 135-171. https://doi.org/10.1086/684844

Sundstrom, A. (2016). Covenants with broken swords: Corruption and law enforcement in governance of the commons. Global Environmental Change, 31, 253-262. https://doi.org/10.1016/j.gloenvcha.2015.02.002

Suryanto, T., Haseeb, M., \& Hartani, N. H. (2018). The Correlates of Developing Green Supply Chain Management Practices: Firms Level Analysis in Malaysia. International Journal of Supply Chain Management, 7(5), 316.

Transparency International. (2017). Corruption perceptions index 2016. Retrieved from https://www.transparency.org/news/feature/corruption_perceptions_index_2016

White, M. D., \& Kane, R. J. (2013). Pathways to career-ending police misconduct: An examination of patterns, timing, and organizational responses to officer malfeasance in the NYPD. Criminal Justice and Behavior, 40(11), 1301-1325. https://doi.org/10.1177/0093854813486269

Wolfe, D. T., \& Hermanson, D. R. (2004). The fraud diamond: Considering the four elements of fraud. The CPA Journal, 74(12), 38-42. 